\title{
MENINGKATKAN MINAT IPA MELALUI IMPLEMENTASI INTEGRASI-INTERKONEKSI KEISLAMAN DI LINGKUNGAN PONDOK PESANTREN AL-ANWARIYAH TEGAL GUBUG KABUPATEN CIREBON
}

\author{
Ria Yulia Gloria \\ IAIN Syekh Nurjati Cirebon \\ riyulgloria@gmail.com
}

\begin{abstract}
ABSTRAK
Dunia pendidikan saat ini sedang berusaha meningkatkan kualitasnya dari berbagai sisi, hal ini karena abad ke 21 yang dikenal sebagai abad pengetahuan. Harapan mendapatkan hasil belajar siswa terus menerus menjadi hal yang perlu diwujudkan. Berbagai cara terus diupayakan agar hasil belajar siswa mencapai hasil yang optimal. Salah satunya yaitu dengan meningkatkan minat siswa terhadap materi pelajaran. Minat siswa terhadap materi pembelajaran sangat berpengaruh terhadap keberhasilan pendidikan, karna siswa yang berminat pada materi pelajaran akan memiliki keinginan kuat untuk menguasai materi pelajaran tersebut. Kita mengetahui bahwa disekolahsekolah yang berbasis pesantren pada umumnya sangat ditekankan pemahaman dalam bidang keagamaan, segala sesuatu akan dikaitkan dengan pengetahuan agama, termasuk disaat mereka mempelajari mata pelajaran sains atau IPA. Karna itu upaya untuk mengintegrasikan sains atau IPA dengan pengetahuan agama menjadi salah satu cara untuk meningkatkan minat belajar para siswa di lingkungan pesantren. Salah satu upaya itu adalah dengan implementasi integrasi interkoneksi keislaman. Setelah dilakukan penelitian, maka hasilnya dapat disimpulkan yaitu, minat siswa terhadap konsep IPAtermasukdalamkategoribaik, hasil observasi dari 9 komponen yang diobservasi terdapat 4 komponen mendapat nilai $100 \%$, berarti semua siswa melakukan hal tersebut yaitu mendengarkan materi yang disampaikan guru, datang tepat waktu, membuat catatan, dan mencatat apa yang dituliskan guru, sedangkan hasil belajar siswa tidak memuaskan, sebanyak 63\% siswa masih mendapat nilai dibawah nilai KKM.
\end{abstract}

Kata kunci : Minat siswa, Integrasi-Interkoneksi Keislaman.

\section{PENDAHULUAN}

Pendidikan merupakan hal yang penting untuk terus ditingkatkan agar bisa bersaing di era global. Dunia pendidikan saat ini sedang berusaha meningkatkan kualitasnya dari berbagai sisi yang berkaitan, hal ini karena abad ke 21 yang dikenal sebagai abad pengetahuan. Depdiknas (2010), menyatakan abad pengetahuan merupakan suatu era dengan tuntutan yang lebih rumit dan menantang. Perubahanperubahan yang terjadi karena perkembangan ilmu pengetahuan dan teknologi yang sangat pesat telah membawa perubahan hampir di semua aspek kehidupan manusia, dan 
hal ini telah membawa manusia ke dalam era persaingan global yang semakin ketat. Untuk itu bangsa kita harus meningkatkan kualitas sumber daya manusia. Dari uraian tersebut maka berbagai cara dilakukan untuk meningkatkan hasil pendidikan baik dari cara mengajar dan juga proses pembelajaran, sistem pendidikan kita senantiasa berjuang untuk mewujudkan semua impian tersebut. Masalah pelik ini menjadi tantangan baik untuk guru, dosen atau siapapun yang berhubungan dengan dunia pendidikan.

Minat siswa terhadap materi pembelajaran sangat berpengaruh terhadap keberhasilan pendidikan, karna siswa yang berminat pada materi pelajaran maka akan memiliki antusias dan keinginan kuat untuk dapat menguasai materi pelajaran tersebut. Sesuai dengan pendapat yang dikemukakan oleh Slameto (2010), Minat sangat berpengaruh pada diri seseorang. Dengan adanya minat seseorang akan melakukan sesuatu hal yang kiranya akan menghasilkan sesuatu bagi diri seseorang tersebut. Dengan demikian upaya meningkatkan minat sangat penting agar apa yang kita harapkan dalam pembelajaran bisa tercapai.

Faktor lain untuk membuat hasil belajar siswa optimal adalah proses pembelajaran, baik itu strategi, pendekatan, metode, teknik maupun model. Beberapa macam cara yang dilakukan dalam proses pembelajaran bisa meningkatkan hasil belajar dan juga minar belajar siswa. Khusus pada penelitian ini karena siswa yang menjadi subjek penelitian adalah siswa pesantren maka perlu pendekatan dan cara mengajarkan materi sesuai dengan lingkungan pesantren. Mengintegrasikan sains dengan keislaman adalah salah satu upaya yang dapat dilakukan untuk mencapai tujuan yang diinginkan.

IPA atau sains dianggap sulit karna banyak konsep yang memerlukan berpikir tingkat tinggi. Untuk memahami IPA siswa dituntut punya daya pikir abstrak yang lebih kuat, juga mempunyai kemampuan untuk memahami gambar, tabel, grafik dan hubungan antar konsep. Menurut Salpeter (2001), di abad ke-21 ini kemampuan belajar, berpikir kreatif, membuat keputusan, dan memecahkan masalah sangat diperlukan dalam mendapatkan pekerjaan, maka pendidikan sains atau IPA seyogyanya dapat membantu siswa untuk mengembangakan pemahaman dan kebiasaan berpikir, sehingga siswa mempunyai kemampuan untuk menjamin kelangsungan hidupnya.

Pendidikan sains di Indonesia masih membutuhkan banyak perhatian agar dapat meningkat kualitasnya, hal ini dikarenakan fakta di dunia Internasional sains di 
Indonesia masih berada diperingkat yang rendah. Rendahnya prestasi sains dapat dilihat dari hasil penelitian tentang asesmen hasil belajar sains yang diselenggarakan oleh Organization for Ekonomic C0-operation and Development (OECD) melalui The Program for International Student Assesment (PISA) tahun 2009 prestasi literasi sains Indonesia untuk anak usia 15 tahun, Indonesia menduduki urutan ke-57 dari 65 negara, sedangkan hasil PISA tahun 2012 Indonesia semakin mengalami penurunan yaitu menduduki urutan ke 64 dari 65 negara, (OECD, 2010; OECD 2013). Maka perlu kiranya mencari solusi agar permasalahan rendahnya pendidikan negara kita bisa diatasi.

Upaya meningkatkan kemampuan sains tidak terlepas dari upaya meningkatkan minatsiswa dalam belajar sains. Ketika siswa merasa memiliki minat dalam mempelajari sesuatu maka hal itu akan menambah motivasi dan semangat dalam mempelajari hal tersebut, dengan demikian maka hasil belajar pun akan meningkat. Menurut Winkel (1996), minat adalah kecenderungan yang menetap dalam subjek untuk merasa tertarik pada bidang atau hal tertentu. Dari pendapat ini maka jelas bahwa adanya ketertarikan sangat penting, dengan tertarik dan berminat pada sains makasiswa pun akan tertarik untuk mempelajari sains.Selain itu minat belajar siswa dipengaruhi oleh tiga aspek antara lain: perhatian siswa pada saat proses belajar mengajar berlangsung, rasa senang siswa, dan rasa ingin tahu siswa. Ketiga faktor ini merupakan salah satu faktor internal yang termasuk dalam aspek psikologis yang mempengaruhi keberhasilan proses belajar siswa. Guru yang berhasil membina kesediaan belajar siswa-siswanya berarti ia telah melakukan hal yang terpenting yang dapat dilakukan demi kepentingan belajar siswa-siswanya. Sebab minat bukanlah sesuatu yang ada begitu saja melainkan sesuatu yang dapat dipelajari (Singer, 1987).

Dari penjelasan tersebut diatas maka kita melihat pentingnya minat dalam rangka meningkatkan kualitas kemampuan sains siswa, siswa pada umumnya adalah seluruh peserta didik dan termasuk siswa yang ada dilingkungan pesantren. Saat ini di lingkungan pesantren pemahaman konsep-konsep IPA masih kurang memuaskan, dari beberapa penelitian atau observasi awal yang dilakukan pada beberapa sekolah yang berbasis Islam diperoleh nilai IPA rata-rata belum memenuhi standar yang memuaskan sesuai dengan yang diharapkan, hal ini mungkin disebabkan oleh beberapa kendala diantaranya metode, sarana dan juga guru. Salah satu yang juga berpengaruh dan 
penting adalah minat dari siswa untuk belajar sains/IPA. Rasa minat akan meningkatkan motivasi siswa pesantren sehingga konsep Sains/IPA dapat lebih dikuasai. Maka penting kiranya untuk menciptakan minat siswa pesantren terhadap IPA. Dari permasalahan ini maka perlu dicari solusi untuk memecahkannya.

Kita mengetahui bahwa disekolah-sekolah yang berbasis pesantren pada umumnya sangat ditekankan pemahaman dalam bidang keagamaan, segala sesuatu akan dikaitkan dengan pengetahuan agama, termasuk disaat mereka mempelajari mata pelajaran sains atau IPA. Karna itu upaya untuk mengintegrasikan sains atau IPA dengan pengetahuan agama menjadi salah satu cara untuk meningkatkan minat belajar para siswa di lingkungan pesantren. Salah satu upaya itu adalah dengan implementasi integrasi interkoneksi keislaman. Karna siswa dilingkungan pesantren lebih banyak menguasai keilmuan tentang keislaman maka dari sisi inilah akan lebih mengena untuk diadakan pendekatan agar minat siswa terhadap IPA dapat diciptakan dengan optimal. Hal ini juga didasari bahwa tujuan belajar adalah membangun karakter peserta didik, sehingga konsep belajar akan tergantung dan berakar pada peserta didik.

Dari uraian diatas maka penting kiranya upaya untuk menciptakan dan meningkatkan minat belajar sains/IPA pada siswa lingkungan pesantren salah satunya adalah dengan implementasi integrasi dan interkoneksi keislaman.

\section{METODE PENELITIAN}

Penelitian ini dilakukan di pesantren Al-Anwariyah, Cirebon. Implementasi integrasi-interkoneksi keislaman diberikan pada santri putri bersamaan dengan jadwal diberikannya materi IPA di pesantren tersebut, materi IPA yang diberikan disesuaikan dengan silabus yang terdapat pada kurikulum 2013.Metode penelitian yang digunakan adalah metode deskriptif kualitatif dan deskriptif inquiry dalam menganalisis pola ilmiah yang terjadi. Sedangkan instrumen yang digunakan adalah lembar observasi, angket dan pedoman wawancara. Observasi dilakukan untuk mengetahui aktivitas yang berhubungan dengan minat IPA pada siswa pesantren Al-Anwariyah. Angket diberikan untuk mengetahui minat siswa berdasarkan indikator minat siswa. Wawancara dilakukan kepada guru dan juga siswa. Pengambilan data dilakukan sebelum dan sesudah implementasi pembelajaran. 
Teknik pengumpulan data dan analisis data pada penelitian ini, disesuaikan dengan instrumen dan jenis data. Menurut Sugiono (2009), dalam mengumpulkan data dapat dilakukan dalam berbagai setting, berbagai sumber, dan berbagai cara/teknik. Adapun teknik pengumpulan data dalam penelitian ini dengan menggunakan wawancara, observasi dan angket.

Tabel .1. Matriks data da analisi data

\begin{tabular}{|l|l|l|l|}
\hline No. & Data & Instrumen & Teknik Analisis \\
\hline 1 & Minat terhadap IPA & Dokumen Wawancara & Deskriptif \\
\hline 2. & Minat terhadap IPA & Lembar Observasi & Deskriptif kualitatif \\
\hline 3. & Respon Siswa & Lembar Observasi & Deskriptif kualitatif \\
\hline 4. & Hasil Belajar & Soal & Deskriptif kualitatif \\
\hline
\end{tabular}

\section{HASIL DAN PEMBAHASAN}

\section{A. Minat siswa Sebelum Implementasi Integrasi-interkoneksi Keislaman}

Pada tahap awal penelitian, sebelum pembelajaran dengan Implementasi Integrasi-Interkoneksi Keislaman, terlebih dulu dilakukan pengukuran bagaimana minat mereka terhadap IPA. Ada dua pengukuran yang dilakukan yaitu dengan wawancara yang dilakukan kepada guru dan juga siswa, kemudian pemberian angket minat yang diberikan kepada siswa.

Dari hasil wawancara kepada guru IPA, peneliti mengetahui bahwa rata-rata minat siswa terhadap IPA sudah cukup baik, menurut guru tersebut hal ini dapat dilihat dari antusias mereka saat pembelajaran berlangsung. Antusias itu terlihat bahwa rata-rata murid selalu datang tepat waktu dan juga dilihat dari kehadirannya yang baik. Siswa juga tertarik dengan pembelajaran IPA, diantara mereka ada yang suka bertanya hal-hal yang berkaitan dengan materi pelajaran IPA.Bahkan menurut guru IPA beberapa siswa sering bertanya sebelum materi IPA selesai dijelaskan oleh guru. Sedangkan mengenai Implementasi Integrasi-Interkoneksi Keislaman, menurut guru IPA tersebut, kadang guru sering menyelipkan ayat-ayat yang relevan dengan materi IPA, dan hampir semua siswa menerimannya dengan antusias.Siswa pesantren memang sangat tertarik dengan ayat-ayat yang berhubungan dengan ilmu pengetahuan, mereka merasa semakin yakin dengan ilmu pengetahuan disaat ada 
ayat- ayat yang mereka ketahui sangat berkaitan dengan materi yang sedang mereka pelajari.

Hasil wawancara dengan beberapa siswa ternyata mereka berminat terhadap IPA, walaupun mereka belum mengerti tentang banyak materi yang dipelajari IPA. Saat peneliti bertanya apakah siswa tau kenapa mereka harus mempelajari IPA, rata-rata siswa tidak mengerti mengapa mereka harus mempelajari IPA. Mereka tidak mengerti apa kegunaan mempelajari IPA dan apa yang dapat mereka lakukan setelah mempelajari IPA. Namun jawaban mereka berubah setelah Implementasi dilakukan, hasilnya mereka mengerti pentingnya mempelajari IPA, mereka mengetahui manfaat mempelajari IPA dan bisa menyebutkan pekerjaan apa yang bisa mereka lakukan setelah mempelajari IPA.

Untuk mengetahui minat siswa yaitu perasaan senang, ketertarikan siswa, perhatian siswa, dan keterlibatan siswadapat dilihat pada tabel 1 berikut.

\section{Tabel 1.Minatsiswaterhadap IPA}

\begin{tabular}{|l|c|c|}
\hline No. Siswa & Jawaban "Ya" & Jawaban "Tidak" \\
\hline 28 & 460 & 184 \\
\hline Rata-rata & $16,42(16)$ & $6,5(6)$ \\
\hline Persentase & $71,39 \%$ & $28,26 \%$ \\
\hline
\end{tabular}

Dari tabel terlihat bahwa rata-rata siswa yang menjawab "ya" pertanyaan angket tentang minat siswa sebanyak 16 siswa atau sama dengan 71,39\%, hal ini berarti minat siswa terhadap IPA termasuk dalam kategori baik. Pada saat ini siswa sebenarnya belum mendapatkan pembelajaran IPA dengan menggunakan integrasi -interkoneksi keislaman. Namun dari hasil awal yang sudah baik dapat dipastikan bahwa rata-rata siswa sebenarnya berminat dalam mempelajari IPA.

\section{B. Minat Siswa setelah Implementasi Integrasi-interkoneksi Keislaman}

Setelah pembelajaran IPA dikaitkan dengan keislaman ternyata minat siswa terhadap IPA masih tetap dalam kategori baik, yaitu siswa berminat terhadap IPA. Baik data menurut hasil wawancara maupun menurut hasil observasi. Ada beberapa peningkatan dalam minat IPA tersebut meskipun tidak semuanya signifikan. Untuk lebih jelasnya dapat dilihat pada tabel berikut : 
Tabel 2.Minatsiswaterhadap IPA

\begin{tabular}{|l|c|c|}
\hline $\begin{array}{l}\text { Jumlah } \\
\text { Siswa }\end{array}$ & Jawaban "Ya" & Jawaban "Tidak" \\
\hline 28 & 482 & 162 \\
\hline Rata-rata & $17,21(17)$ & $5,8(6)$ \\
\hline Persentase & $74,84 \%$ & $25,15 \%$ \\
\hline
\end{tabular}

Perbandingan anatara minat belajar IPA siswa sebelum Implementasi Integrasi-Interkoneksi Keislaman dengan setelah Implementasi IntegrasiInterkoneksi Keislaman, dapat kita lihat pada diagram berikut.

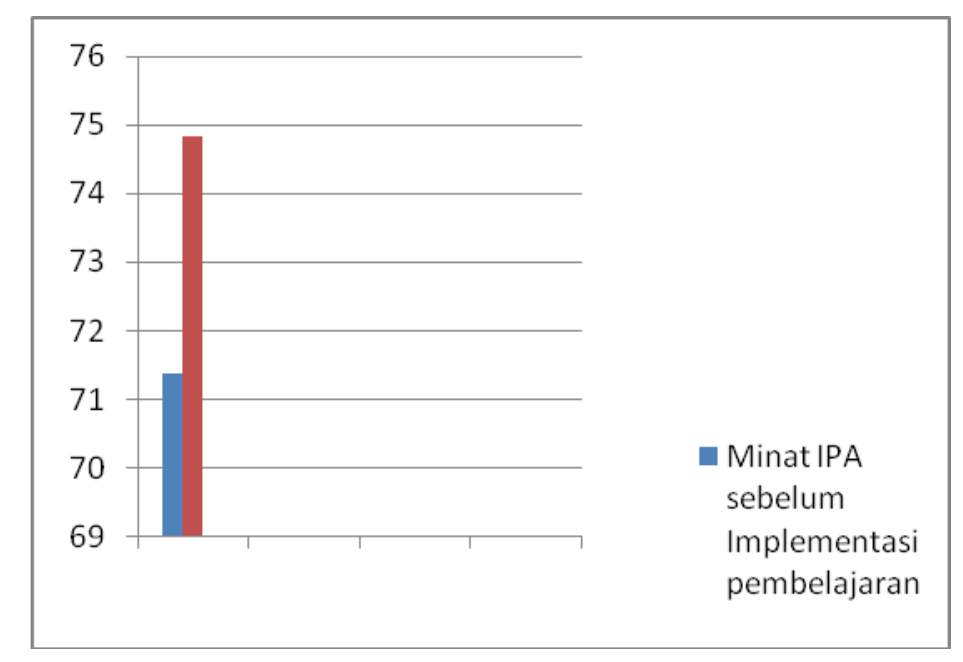

Gb.1. Diagram Minat siswa terhadap IPA

Dari diagram terlihat bahwa minat siswa terhadap IPA meningkat dari $71 \%$ menajdi sekitar $75 \%$, peningkatan ini membuktikan bahwa pembelajaran dengan menggunakan Implementasi Integrasi-Interkoneksi Keislaman membuat siswa jadi lebih memiliki perasaan senang, siswa menjadi lebih tertarik, siswa menjadi lebih memperhatikan pelajaran, dan siswa ikut terlibat dalam pembelajaran. Artinya semua indikator minat siswa dapat terpenuhi.

Peningkatan minat ini menjelaskan bahwa pembelajaran dengan Implementasi Integrasi-Interkoneksi keislaman baik dalam upaya meningkatkan minat siswa yang nantinya akan berpengaruh pada kualitas pembelajaran. Hal ini sesuai dengan apa yang diungkapkan Slameto (2010), Minat sangat berpengaruh pada diri seseorang. Dengan adanya minat seseorang akan melakukan sesuatu hal 
yang kiranya akan menghasilkan sesuatu bagi diri seseorang tersebut.Hal ini juga dijelaskan Tidjan (1976), minat adalah gejala psikologis yang menunjukkan pemusatan perhatian terhadap suatu objek sebab ada perasaan senang. Sedangkan definisi menurut Mahmud (1982), minat adalah kekuatan pendorong yang memaksa seseorang menaruh perhatian situasi atau aktifitas tertentu dan bukan pada orang lain, dengan demikian sesuatu yang menarik seseorang maka akan meningkatkan minat orang tersebut. Kesimpulannya adalah Implementasi IntegrasiInterkoneksi Keislaman telah membuat siswa pesantren Al-Anwariyah menjadi semakin berminat dalam mempelajari IPA.

\section{Aktivitas Siswa dan Hasil Belajar Siswa pada Impelementasi Integrasi Interkoneksi Keislaman.}

Hasil Observasi mengenai implementasi Integrasi Interkoneksi Keislaman terlihat bahwa dari 9 komponen yang diobservasi terdapat 4 komponen mendapat nilai $100 \%$, berarti semua siswa melakukan hal tersebut yaitu mendengarkan materi yang disampaikan guru, datang tepat waktu, membuat catatan, dan mencatat apa yang dituliskan guru. Kenyataan ini bisa menunjukkan minat siswa sesuai dengan pendapat Tidjan (1976), minat adalah gejala psikologis yang menunjukkan pemusatan perhatian terhadap suatu objek sebab ada perasaan senang. Sedangkan definisi menurut Mahmud (1982), minat adalah kekuatan pendorong yang memaksa seseorang menaruh perhatian situasi atau aktifitas tertentu dan bukan pada orang lain.

Dari hasil observasi aktivitas yang paling sedikit dilakukan adalah bertanya tanpa disuruh, siswa masih sangat malu-malu untuk bertanya, dari pengamatan peneliti rata-rata siswa di pesantren ini memang sangat santun, hal ini pula yang membuat mereka sulit untuk bertanya di kelas apabila tidak disuruh. Sebaliknya jika disuruh bertanya barulah mereka mau bertanya. Hal ini pula yang menunjukkan rendahnya inisiatif dari mereka, sehingga pembelajaran terkesan tidak aktif dan tidak menarik. Selama pembelajaran berlangsung meskipun guru sudah berusaha untuk mengaktifkan siswa, misalnya dengan bercanda dan sesekali melontarkan pertanyaan, namun sangat sedikit siswa yang merespon hal tersebut. Beberapa 
pertanyaan dari guru sering tak mau dijawab oleh siswa, kendati guru telah menunjuk siswa agar menjawab.

Aktivitas pada observasi yang ke tiga juga termasuk katagori nilai rendah yaitu $15,8 \%$ yaitu untuk siswa yang membaca materi sebelum belajar. Hal ini tentu berpengaruh terhadap pembelajaran, karena tanpa membaca terlebih dulu materi yang akan diajarkan maka siswa betul-betul tidak punya wawasan sedikitpun tentang apa yang akan mereka pelajari.

Untuk aktivitas yang ke empat yaitu beraktivitas saat guru menjelaskan, ada 7 dari 19 siswa atau 36,8\% yang melakukan aktivitas, seperti mencatat, bertanya pada teman, dan aktivitas yang lainnya. Kebanyakan siswa lebih suka diam dan mendengarkan saja apa yang dijelaskan oleh guru. Hampir semua siswa terlihat selalu setuju dengan apa yang dijelaskan oleh guru. Hal ini sebenarnya agak mengecewakan karena ini seolah menunjukkan mereka sangat pasif dan menerima semua tanpa dipikirkan.

Aktivitas yang ke delapan yaitu bertanya saat disuruh, hanya ada satu siswa yang melakukan hal tersebut. Maka hal itu menunjukkan keingintahuan siswa terhadap materi yang sedang dipelajari sangat rendah. Aktifitas bertanya tanpa disuruh juga menunjukkan hal yang sama. Rata-rata siswa tidam mau bertanya. Ada dua kemungkinan dari kenyataan tersebut, yaitu siswa sudah merasa apa yang disampaikan gurunya sudah cukup jelas atau sebaliknya siswa sangat tidak mengerti dengan materi yang disampaikan oleh guru.

Aktivitas siswa penting diketahui untuk menunjukkan minat siswa, bagaimana minat siswa terhadap IPA bisa tercermin dari aktivitasnya. Sesuai dengan indikator minat yang terdiri atas perasaan senang, ketertarika siswa, perhatian siswa dan keterlibatan siswa.Dari pengamatan terhadap aktivitas itulah maka kita bisa memperoleh gambaran sejauh mana minat siswa terhadap pembelajaran tersebut. Hal ini juga sesuai dari berbagai pendapat mengenai minat siswa, diantaranya adalah Menurut Tidjan (1976), minat adalah gejala psikologis yang menunjukkan pemusatan perhatian terhadap suatu objek sebab ada perasaan senang. Sedangkan definisi menurut Mahmud (1982), minat adalah kekuatan pendorong yang memaksa seseorang menaruh perhatian situasi atau aktifitas tertentu dan bukan pada orang lain, menurut Slameto (2010), Minat sangat berpengaruh pada diri seseorang. 
Semua orang secara umum mengetahui bahwa minat seseorang akan berpengaruh terhadap aktivitas orang tersebut, karna minat bisa menunjukkan mengapa seseorang melakukan sesuatu. Minat dapat menjadi daya penggerak seseorang untuk melakukan beberapa aktivitas. Minat akan menjadi aktif terutama bila kebutuhan untuk mencapai sesuatu sangat dirasakan dan mendesak.

Minat siswa ini sebenarnya sangat berhubungan dengan motivasi siswa juga, menurut Sadirman (2007), motivasi muncul karena adanya kebutuhan, begitu juga minat sehingga tepatlah kalo minat merupakan alat motivasi yang pokok. Proses belajar akan berjalan dengan lancar kalau disertai dengan minat.

\section{Hasil Belajar}

Untuk mengetahui efektifitas dari implementasi integrasi interkoneksi keislaman, maka setelah implementasi dilakukan siswa diberi tes untuk mengetahui hasil belajarnya. Tes dilakukan yaitu setelah pembelajaran selesai. Hasil belajar siswa ini diambil untuk bisa menggambarkan bagamana pemahaman siswa setelah proses pembelajaran berlangsung.

Soal yang diberikan dalam tes untuk mengetahui hasil belajar adalah soal yang diberikan setelah mengajar dengan Implementasi Integrasi-Interkoneksi Keislaman. Tes hasil belajar hanya dilakukan sekali saja, hal ini cukup untuk mengetahui bagaimana pemahaman siswa setelah pembelajaran berlangsung. Dari data hasil belajar siswa diperoleh dari 19 siswa, diperoleh rata-rata nilai siswa sebesar 64,4 perbedaan nilai antar siswa terlihat jelas. Nilai terbesar adalah 91,7 sedangkan yang terkecil adalah 33,3. Hanya 37\% yang memiliki nilai diatas KKM (70), sehingga bisa disimpulkan hasil belajar siswa tidak memuaskan.Nilai diatas KKM yaitu 7 orang atau sebanyak $37 \%$, ini berarti termasuk dalam kategori sangat kurang.

Kurangnya nilai hasil belajar dari siswa ternyata tidak sejalan dengan hasil angket mengenai minat siswa terhadap implementasi pembelajaran IntegrasiInterkoneksi keislaman, dimana minat belajar siswa termasuk kedalam kategori baik yaitu rata-rata siswa berminat dengan pembelajaran tersebut. Menurut Mahmud (1982), minat adalah kekuatan pendorong yang memaksa seseorang menaruh perhatian situasi atau aktifitas tertentu dan bukan pada orang lain, sedangkan menurut Slameto (2010), Minat sangat berpengaruh pada diri seseorang. Dengan 
adanya minat seseorang akan melakukan sesuatu hal yang kiranya akan menghasilkan sesuatu bagi diri seseorang tersebut. Dari dua pendapat ini seharusnya jika siswa berminat maka hasil belajarpun akan baik, karna ketertarikan siswa terhadap pembelajaran dapat membuat siswa lebih mudah memahami materi pelajaran.

Dari hasil belajar siswa yang masih kurang, ada kemungkinan bahwa siswa masih kesulitan dalam mempelajari IPA. Materi IPA masih dianggap materi yang sulit untuk dipahami, maka masih perlu usaha lebih keras untuk meningkatkan hasil belajar. Dari hasil tersebut juga diketahui minat IPA tidak selalu mendukung terhadap peningkatan hasil belajar siswa. Terbukti beberapa siswa masih tetap kesulitan dalam menjawab pertanyaan-pertanyaan yang ada pada soal tes.

\section{KESIMPULAN}

Dari hasil dan pembahasan berdasarkan penelitian yang telah dilakukan, maka dapat diambil kesimpulan sebagai berikut ;

1. Minat siswa pesantren Al-Anwariyah Tegal Gubug Lor Arjawinangun Cirebon terhadap konsep IPAtermasukdalamkategoribaik, artinya pada umumnya siswa berminat dengan pembelajaran tersebut. Hasil ini menjelaskan minat baik sebelum maupun sesudah pembelajaran.

2. Hasil Observasi mengenai implementasi Integrasi Interkoneksi Keislaman terlihat bahwa aktivitas siswa termasuk kategori baik, dari 9 komponen yang diobservasi terdapat 4 komponen mendapat nilai $100 \%$, berarti semua siswa melakukan hal yaitu mendengarkan materi yang disampaikan guru, datang tepat waktu, membuat catatan, dan mencatat apa yang dituliskan guru.

3. Hasil belajar siswa setelah Implementasi Integrasi Interkoneksi Keislamantidak memuaskan, dilihat dari rata-rata siswa yang memperoleh dibawah nilai diatas KKM hanya $37 \%$, ini berarti termasuk dalam kategori sangat kurang. 


\section{DAFTAR PUSTAKA}

Al-Rehaili, Abdullah M. 2003. Bukti Kebenaran Qur'an. Yogyakarta : Padma

As Shouwy, dkk. 1995. Mukjizat Al Qur'an dan As-Sunnah tentang IPTEK. Jakarta : Gema Insani Press

Azis, Fajar Sultoni. 2008. "Implementasi Paradigma Integrasi-Interkoneksi dalam Pembelajaran Fisika”. SKRIPSI : Universitas Negeri Sunan Kalijaga Yogyakarta.

Bagir, Zaenal Abidin. 2008. Islam dan Ilmu Pengetahuan. Research \& Development Center for Philosophi, Science, Civilization and Spiritualism. [on line].pada tanggal 20 agustus 2014.

Baiquni, Ahmad. 1997. AlQur'an dan Ilmu Pengetahuan Alam. Yogyakarta : PT. Dana Bhakti Prima Yasa.

Depdiknas. 2010. Paradigma Pendidikan Nasional Abad XXI. Jakarta : BNSP.

Djamarah, Syaiful Bahri.2002. Strategi Belajar Mengajar. Jakarta: Rineka Cipta.

Imron.2014. Makalah Islam dan Ilmu Pengetahuan.

Mulyono . 2011.jurnal penelitian keislaman vol 7 no 2

OECD. (2010). PISA 2006: Science Competencies for Tomorrow's World Eksecutive Summary. [on line]. Tersedia :http//dx.doi.org/10.1787/888932343342. [28 April 2014].

OECD. (2013). PISA 2012: Result: Eksecutive Summary. [on line]. Tersedia :http//dx.doi.org/10.1787/888932343342. [28 April 2014].

Sadirman. 2007. Interaksi dan Motivasi Belajar Mengajar. Jakarta : PT. Raja Grafindo Persada.

Safa'atun. 2013. "Pengembangan Model IPA Fisika Berbasis Integrasi-Interkoneksi untuk Siswa SMP/MTs. SKRIPSI. ProgramStudi Pendidikan Fisika Fakultas Sains dan Teknologi Universitas Islam Negeri Sunan Kalijaga. Yogyakarta.

Saksono, Tono. 2006. Manusia Mengiringi Simponi Dzikir Alam Semesta tanpa henti. Bekasi: RBT

Salpeter. 2001. Century Skill: Have Student Ready. [Online]. Tersedia http://www.21st Centuryskill.org. [April 2013].

Slameto. 2010. Belajar dan Faktor- Faktor yang Mempengaruhinya. Jakarta: Rineka Cipta

Siagian, Roida Eva Flora. Pengaruh Minat dan Kebiasaan Belajar Siswa Terhadap Prestasi Belajar Matematika.Jurnal Formatif 2(2): 122-131 ISSN: 2088-351X

Singer, K. (1987). Membina Hasrat Belajar di Sekolah. Bandung: Remaja Karya

Sugiyono, 2012.MetodePenelitianPendidikanPendekatanKuantitatif, Kualitatif, dan $R$ \& D. Bandung: Alfabeta.

Usman, Uzer. (2003). Menjadi guru profesional.Bandung:Penerbit PT RemajaRosdakarya

Yahya, harun. 2002. Pernahkah Anda Merenung Tentang Kebenaran. Jakarta : Robbani Press.

2008. Keajaiban Al Qur'an. Bandung : Arkan Publishing

Winkel,W. S1996. Psikologi pengajaran. Jakarta : Grasindo 